\title{
The Doha Trade Round and Mozambique
}

by

Channing Arndt*

Chapter 5 in Putting Development Back into the Doha Agenda: Poverty Impacts of a WTO Agreement, Thomas W. Hertel and L. Alan Winters (eds.) forthcoming from the World Bank, Washington, DC

World Bank Policy Research Working Paper 3717, September 2005

The Policy Research Working Paper Series disseminates the findings of work in progress to encourage the exchange of ideas about development issues. An objective of the series is to get the findings out quickly, even if the presentations are less than fully polished. The papers carry the names of the authors and should be cited accordingly. The findings, interpretations, and conclusions expressed in this paper are entirely those of the authors. They do not necessarily represent the view of the World Bank, its Executive Directors, or the countries they represent. Policy Research Working Papers are available online at http://econ.worldbank.org.

* Ministry of Planning and Development, Mozambique and Associate Professor Purdue University. 


\section{Summary}

This paper considers the potential implications of the Doha Development Agenda, as well as other trade liberalization scenarios, for Mozambique. An applied general equilibrium model, which accounts for high marketing margins and home consumption in the Mozambique economy, is linked to results from the GTAP model of global trade. In addition, a microsimulation module is employed to consider the subsequent implications of trade liberalization for poverty. The implications of trade liberalization, particularly the Doha scenarios, are found to be relatively small. Presuming that a more liberal trading regime will positively influence growth in Mozambique, an opportunity exists to put in place such a regime without imposing significant adjustment costs. 


\section{Introduction}

The Doha round of trade negotiations seeks explicitly to involve developing countries. In terms of process, developing countries are expected, as a group, to be much more engaged in the actual negotiations. Wealthier nations, on their side, are expected to place greater emphasis on the implications of any agreement for the developing countries, and particularly for poverty. The hope is to reach an agreement that enhances opportunities for developing countries to achieve poverty reducing economic growth through stronger trade linkages with the world economy.

As the region with the highest rate of poverty and relatively weak linkages into the global economy, it seems logical to carefully consider the role of Africa within the Doha agenda. The African continent is both enormous and highly diverse. As a result, implications of any given global trade agreement will differ across economies on the continent. This paper considers the potential implications of trade liberalization scenarios for the case of Mozambique. Like all African economies, Mozambique has distinguishing features that render it unique. However, as will be discussed, it also shares many structural features with other African countries. The logic of some of the ideas developed here can therefore be applied to a number of other countries across the continent.

The paper is structured as follows. Section 1 presents a brief description of Mozambique. Section 2 considers implications of various trade liberalization scenarios derived from an analysis that marries outputs from the GTAP model of global trade with a more detailed country computable general equilibrium (CGE) model of Mozambique. Poverty analysis proceeds using a separate household microsimulation module. Section 3 provides a critique of the main results that come out of the models. Section 4 concludes. 
The transmission of prices to low-income households is a theme that is developed in particular detail throughout the paper.

\section{Mozambique}

Mozambique is located along the South Eastern coast of Africa. In terms of total area, coastline and shape, it is roughly similar to (a mirror image of) the combined areas of the states of California, Oregon, and Washington that make up the western coast of the United States. Exploitation of natural resources underpins a substantial share of economic activity. Fisheries comprise a major export industry. The stock of arable land is large and much arable land remains unexploited. Important agricultural exports include cotton and tobacco. Forestry is also important. With its long coastline and abundance of natural harbors, Mozambique provides port and transport services to neighboring countries. Exploitation of natural gas, uranium, titanium, and other mineral resources has also begun. Finally, Mozambique's natural beauty, particularly her beaches and coral reefs, attracts tourists.

These favorable attributes are spread out over a relatively small population of not quite 19 million people. Nevertheless, more than half of the population is categorized as absolutely poor. This implies that slightly more than one person in two has difficulty in meeting very basic survival needs in terms of calorie consumption and basic non-food necessities such as housing and clothing.

This pervasive poverty is the result of a complex historical legacy that included weak human capital development over the colonial period even by African standards, failed socialist policies initiated shortly after independence in 1975, and finally, a brutal 
civil war that endured for more than a decade. The cessation of hostilities in 1992 coincided with one of the worst droughts on record. The cumulative effect of these disasters earned Mozambique the unwanted moniker of "poorest country in the world" in the early 1990s. Since then, the economic record has been considerably more positive. From a low base, economic growth has averaged in the range of 7-8 percent per annum for more than a decade. This growth coincided with the implementation of a fairly standard structural adjustment program. Very considerable flows of external assistance clearly helped to fuel growth and provided major funding for social initiatives with particularly large investments in basic health and education. ${ }^{1}$

By most objective indicators, living conditions for the Mozambican population have improved considerably. In 1996-97, about 69 percent of the population was characterized as absolutely poor using real consumption as a metric. By 2002-03, this number had fallen by 15 percentage points to about 54 percent using the same metric. Indicators such as crop production, asset ownership, income of rural households, school enrollments, infant mortality, and child vaccination coverage rates also showed improvements (MPF et al. 2004).

Because initial development levels were so low, a decade plus of rapid growth and rapid improvement in many social indicators has placed Mozambique near SubSaharan African averages for a range of indicators. In short, the trends are positive but the absolute levels of such indicators remain dismal. The clear challenge is to maintain the positive momentum developed over the past decade.

Over the coming decade, international trade will likely play a prominent role if growth is to continue. Growth in the past decade has been driven in large measure by

\footnotetext{
${ }^{1}$ For a more complete historical review, see Arndt, Jensen, and Tarp (2000).
} 
internal reconstruction needs (usually donor funded) and production of basic goods and services that often have been consumed at very local levels, frequently within the household where they are produced. ${ }^{2}$ While these sources of demand are likely to continue to be important, at least through the medium term, there is also a clear need to strengthen links to international markets, particularly with respect to exports of labor intensive products.

This thumbnail sketch illustrates many aspects of Mozambique that are unique on the African continent. However, Mozambique also shares many essential structural features that are quite common. A non-exhaustive list includes:

- A predominantly rural population with economic and social indicators typically at less favorable levels in rural areas. Hence, the large majority of the poor reside in rural areas making improvements in the well-being of current rural dwellers practically a condition sine qua non of any significant reduction in overall poverty levels.

- An overwhelming dependence on agriculture in rural areas.

- Large distances and poor transport infrastructure which result in substantial transport costs particularly between distant regions. These weaken or even sever entirely market linkages across disparate regions of the country. For example, the cost of transporting maize by truck from growing regions in the North to the capital city, located in the far South, is so high as to be effectively prohibitive.

\footnotetext{
2 "Big projects", such as the Mozal aluminum smelter, have contributed considerably to GDP but very little to GNP.
} 
We now consider implications of the Doha Development Agenda derived from a formal applied general equilibrium (AGE) model of Mozambique that is linked to outputs from the GTAP model of global trade.

\section{Modeling the Implications of Doha}

The goal of trade liberalization is to redirect productive resources to areas of comparative advantage. At the global level, this implies that production patterns will shift across countries. Within countries, some industries are likely to contract, thereby freeing productive resources which, at least in principle, might allow other industries to expand. Typically, one expects productive patterns within individual countries to concentrate in particular industries that have a comparative advantage, following trade liberalization. Surplus production is sold on global markets, and the resulting income permits countries to import products that were formerly produced at home.

Since the goal of trade liberalization frequently involves the reallocation of resources across productive sectors, CGEmodels have come to be the workhorses for analyses of trade agreements. This paper focuses on the Mozambique model, including the microsimulation module for poverty analysis. The first sub-section provides a description of the basic features of the Mozambique model. The second sub-section discusses structural features of the economy that can be expected to drive model results. The third sub-section presents salient model results.

\subsection{The Mozambique CGE Model}

We start from a standard, trade-focused CGE model, which contains three basic

elements: (a) specification of economic behavior for firms and households; (b) operation 
of markets; and, (c) macroeconomic closure. ${ }^{3}$ Novel features particularly relevant for this analysis are then discussed.

\section{Behavioral Specification}

The model assumes profit maximization by producers under a sectoral constant elasticity of substitution (CES) technology. Consumers are assumed to demand commodities according to a linear expenditure system (LES) utility function formulation. Investment and government expenditures are allocated in a Leontief fashion, with fixed real coefficients rather than fixed expenditure shares.

Foreign trade is specified using the Armington assumption. There are CES functions for sectoral imports. Armington import elasticities are taken from Hertel, Hummels, Ivanic, and Keeney (2004). A constant elasticity of transformation (CET) function is employed on the export side. However, in order to remain consistent with the GTAP model, the sectoral export transformation elasticities were set to a high values (5). And, a downward sloping demand function for Mozambican exports was developed again using elasticities from Hertel, Hummels, Ivanic, and Keeney (2004). The presence of these downward sloping demand functions permits the Mozambique country model to simulate both the world price changes and the shifts in demand generated by the GTAP model under various global trade liberalization scenarios. ${ }^{4}$

\footnotetext{
${ }^{3}$ Löfgren, Harris and Robinson (2001) and Tarp, Arndt, Jensen, Robinson and Heltberg (2002) provide detailed explanations of the basic CGE model that was revised for the purposes of this analysis.

${ }^{4}$ Downward sloping export demand functions offer the considerable advantage of consistency with the global modeling framework. Disadvantages are discussed in detail in the penultimate section which presents a critique of the current model.
} 


\section{Operation of Markets}

A CGE model simulates the operation of product and factor markets, solving for market-clearing prices and wages. It is a closed general equilibrium system, incorporating all elements of the circular flow of income and expenditure, and the corresponding real flows. Characteristic features of this type of model include:

a) Households must respect their budget constraint;

b) The domestic price of imports equals the CIF price multiplied by the exchange rate and the prevailing tariff rate plus any marketing margins or additional domestic sales taxes;

c) The value of imports cannot exceed the availability of foreign exchange;

d) Supply of commodities must equal demand for commodities (with inventory accumulation counted as demand);

e) Firms collectively cannot use more of any factor than the total availability in the economy;

f) Investment must be financed via foreign or domestic savings; and,

g) Government consumption must be financed through tax revenue, foreign grants (aid), or borrowing on domestic or foreign markets.

Also, in this model, aggregate employment of all factors of production is exogenous and factor returns adjust to clear factor markets. Finally, the model numeraire is the consumer price index, so all price changes reported are relative to the CPI.

\section{Macro Closure}

All CGE models incorporate macro balances. How equilibrium is achieved between savings and investment, the government deficit, and the trade deficit constitutes 
the "macro closure" of the model. In the Mozambican model, aggregate investment is determined by savings (private plus government plus foreign) so the model is "savings driven”. Private savings are endogenous, depending on fixed savings rates by households and enterprises. Government expenditure is set as a fixed share of aggregate absorption in the economy, and the government deficit is exogenous. Direct tax rates across institutions (households and enterprises) vary in order to maintain a constant deficit. Foreign savings and aid are fixed exogenously and the real exchange rate adjusts to achieve external balance through changes in aggregate exports and imports.

\section{More Novel Features}

Importantly for this analysis, the CGE model employed specifically accounts for the substantial costs required for products to reach commercial markets. This is particularly important in the case of agricultural products. These marketing margins reflect storage and transportation costs, as well as risk associated with trading activities and limited opportunities for diversification. Marketing margins are introduced into the static CGE model by assuming that each unit of a given production good requires a fixed amount of marketing services to reach the market. Since the current model framework treats imported and exported goods as inherently different from domestically consumed production, marketing margins related to exports, imports, and domestic goods are accounted for separately. A single production activity provides the commercial services associated with the marketing of commodities.

Transaction costs vary across sectors. They are zero in the case of service sectors, by definition, while they are nonzero - and sometimes quite large -- in other goods sectors, particularly agricultural sectors where products are bulky and distances between 
points of production and consumption can be large. Marketing costs also vary depending on whether the product is imported, exported, or domestically produced and marketed.

Almost all Mozambican households have some money income, either from goods sales or from factor remunerations. This income is used for purchases of essential goods that cannot be produced by the households themselves. Nevertheless, the possibility of home consumption enables households to bypass the market in so far as they can produce consumption goods themselves. The presence of high marketing margins implies the existence of significant differences between farm gate (and factory gate) sales prices, on the one hand, and prices in the commercial markets on the other hand. Rather than sell at a low price and purchase at a high price, households—particularly rural agricultural households—often opt to consume at least some of what they produce. In some cases these marketing margins are so large as to isolate the household from commercial markets altogether. Therefore, explicit modeling of the interaction between marketing costs and home consumption becomes essential for assessing important aspects of the economy. Home-consumed and market consumption of all commodities are captured in the linear expenditure system (LES) formulation mentioned above. Appropriate modeling of home consumption and marketing margins has been shown to be important (Arndt, Jensen, Robinson, and Tarp 2000).

\subsection{The Mozambique Micro-simulation Model}

A micro-simulation model in the spirit of Chen and Ravallion (2004) is developed to examine the poverty implications of the trade liberalization scenarios analyzed. The model relies upon data from the 2002-03 Mozambican Household survey, known as IAF 2002-03 (INE 2004). The survey provides detailed information on consumption patterns 
for a nationally representative sample of 8,700 households. The survey also provides detail on household members including sector of economic activity and education level. The analysis examines the first order implications of the changes in commodity prices and factor prices generated by the Mozambican CGE model for each of the 8,700 households in the sample. Specifically, changes in commodity prices are multiplied by individual household consumption shares and changes in factor prices are multiplied by the corresponding share of earnings from each factor in total household income. The factor price effect less the commodity price effect yields a money metric indicator of the first order change in utility due to the trade reforms for each household.

Importantly, in first order analysis, the net of effect of price changes for commodities that are home produced/consumed is zero as commodity price changes are exactly offset by gains or losses in factor income. This tends to blunt the impact of trade policy reform on rural households. As mentioned above, and detailed in the following section, home consumption is very important in the Mozambican context. In addition, the overwhelming predominance of informal activities implies that wage information is scarce. As a result, earnings by labor category are inferred from educational attainment data and returns to education estimated via regression analysis (Maximiano 2005). Similarly, for the large majority of households, it is practically impossible to separate overall household earnings into labor and capital components. This is less of an issue for poor households as the large majority of earnings can reasonably be assumed to be derived from labor income. In the micro-simulation model, five percent of total income is assumed to come from capital earnings for households living at less than twice the absolute poverty line. 


\subsection{Structure of the Mozambican Economy}

Tables 1, 2, and 3 provide an overview of the structure of the Mozambican economy. Table 1 reports the macroeconomic aggregates. For a very poor country, Mozambique allocates fairly substantial resources to government consumption and government investment. The relatively high level of government expenditure is enabled by substantial inflows of external assistance, which are typically used to support government spending and public investment. These same foreign inflows permit Mozambique to run a trade deficit, with the value of imports substantially exceeding the value of exports.

Table 2 indicates the sectoral structure of production and trade. Agriculture, forestry, and fisheries amount to about $25 \%$ of GDP at factor cost. Trade and transport amount to another $25 \%$ and construction to nearly $10 \%$. More than half of total exports come from two primarily foreign-owned island sectors. Aluminum smelting alone accounted for $48 \%$ of the value of total exports in 2001. Exports of electricity from the Cahora Bassa dam in Northern Mozambique accounted for another nearly 10\% of total exports. Unfortunately, the large majority of these export revenues are used to pay for imported intermediates, salaries for expatriate personnel, and repatriation of profits. Hence, the links to the Mozambican economy are relatively small. ${ }^{5}$ Fisheries provide the next most important source of export revenue. Imports tend to be concentrated in processed food, fuel, and manufactures, particularly transport equipment and other capital goods.

\footnotetext{
${ }^{5}$ Aluminum smelting is modeled as an island sector. Nearly $100 \%$ of production is exported. Returns to capital from aluminum smelting are assumed to be repatriated abroad.
} 
Average tariff rates by commodity are also included in the table. The rates implied by the social accounting matrix originally developed for this analysis are presented under the heading "average tariffs" and the rates used in the GTAP model of global trade are presented under the heading "GTAP tariffs". Generally, the tariffs implied by the SAM correlate well with those employed in the GTAP model (the correlation is about 0.58 ), even though the methodologies for developing these tariff aggregates have been rather different.

Table 3 is meant to provide a better sense of the degree of competition between imports and domestic production. The results in the table are derived from an analysis of local production and imports comprising all economic activity divided into 144 sectors. Each of the 144 sectors was put into one of three groups. The first group contains sectors where production accounts for at least 90 percent of total availability (production plus imports). The second group contains sectors where imports account for at least $90 \%$ of total availability. The third group contains all remaining products. This third group contains sectors where neither domestic supply nor imports dominate the total supply of the commodity. The first two groups are considered to be "specialized" while the remaining third group is considered "non-specialized".

Table 3 indicates that, in general, sectors tend rather strongly to be either dominated by imports or by domestic production. Overall, about $89 \%$ of the value of domestic production is specialized with the large majority of these facing minor to no import competition in their particular product category. ${ }^{6}$ The sectors that compete most

\footnotetext{
${ }^{6}$ Substitution across commodities would amplify competition. So, for example, maize production faces little direct import competition in the form of imported maize. However, significant volumes of wheat and rice are imported. Since maize meal and bread are substitutes, domestic maize competes indirectly with imports through the potential for consumers to alter dietary choices.
} 
directly with imports are in primary product processing, which includes processed foods. According to the table, 53 percent of sales in this category come from sectors that are specialized (either dominated by imports or by domestic production). This implies that slightly less than half of sales in these sectors are in sectors where both imports and domestic production account for a significant volume of total domestic supply. These sectors also benefit from fairly substantial tariff protection (see Table 2). However, these sectors comprise only about 14 percent of the value of total sales and a smaller percentage of value added.

Generally, the volume of resources located in sectors where import competition could be expected to be keen is relatively small. There is little to no possibility for substitution between domestic production and imports in sectors where imports are dominant, such as oil, vehicles, and capital goods. Mozambique quite simply has very little to no productive capacity in these areas. Consequently, imports are expected to dominate under any scenario. Similarly, where production values for tradeables are large, such as in primary agriculture and fisheries, import volumes tend to be minor. Import volumes are also minor in most service sectors.

With respect to households, home consumption of basic food items represents a very important element of total expenditure. The importance of home consumption, from various perspectives, is presented in Table 4. According to the macroeconomic accounts, home consumption amounts to 22 percent of total consumer expenditure on commodities. Home consumption is much more prevalent in rural than in urban areas. Home consumption amounts to about 36 percent of total rural consumer spending and only about $8 \%$ of total urban consumer expenditure. 
Wealthy households whose population weight is small but whose economic weight is large tend to dampen significantly the importance of home consumption in the macroeconomic accounts. Since wealthy individuals tend to engage in very little home consumption as a share of total consumption and have large economic weight, their presence drives down the share of home consumption in the macroeconomic data. When home consumption shares are derived using population weights (e.g., what is the share of home consumption for the average household), the share of home consumption grows considerably. At the national level, the average household obtains 45 percent of the value of total consumption from home consumption. The average rural household share remains considerably higher than the urban household share at 58 percent and 16 percent respectively.

The population categorized as poor tends to home consume proportionately somewhat more than the national average. Nevertheless, in terms of share of goods home consumed, households characterized as poor are not all that different from the population average. This not surprising when one considers the fact that the poor represent more than half the population. In addition, a further large fraction of the population consumes at levels above but still near the poverty line. For example, $90 \%$ of the population consumes at levels less than twice the poverty line. The tendency to home consume apparently remains relatively constant across these basic levels of income.

\section{$2.4 \quad$ Inequality}

James, Arndt, and Simler (2005) conduct a detailed analysis of inequality based on the 2002-03 Household survey for Mozambique. They estimate a national Gini coefficient of 0.42 , which represents a fairly high degree of inequality, though not out of 
line with other sub-Saharan African countries. ${ }^{7}$ Table 5 shows an index of real consumption by quintile. Families in the highest quintile consume about eight times the value for the poorest quintile. Inequality varies by region with consumption tending to be more evenly distributed in rural than in urban zones (a standard result). Regional differences also exist with the South, especially the capital city Maputo, exhibiting much greater degrees of inequality.

\section{$2.5 \quad$ Simulations and Results}

Table 6 describes the shocks applied in the simulations analyzed and Table 7 describes the simulations. Results from the GTAP model of global trade are transmitted to the Mozambique model via changes in import prices and export prices and quantities faced by Mozambique. Import price changes are simply applied to the exogenous import prices in the Mozambique model. Export price and quantity changes derived from the GTAP model are applied in the manner developed by Horridge (2004). Specifically, an export demand function of the form: $\mathrm{Q}=[\mathrm{FP} / \mathrm{P}] \wedge \mathrm{ESUBM}$ (where $\mathrm{Q}$ is the quantity exported, $\mathrm{P}$ is the export price, ESUBM is the elasticity of demand for exports, and FP is a shift parameter) has been added to the Mozambique model in order to mimic the global GTAP model. Horridge (2004) shows that export price and quantity changes generated by GTAP can be mimicked in a country through shocks to the shifter parameter FP. Using lower case to indicate percentage change, the percentage change in FP applied to the Mozambique model can be derived as follows: $f p=p+q / E S U B M$.

The four simulations presented are detailed in Table 7. These are unilateral complete trade liberalization (Unilib), global trade liberalization with Mozambique not

\footnotetext{
${ }^{7}$ For example, the Gini coefficient is 0.43 in Uganda (Uganda 2003).
} 
participating (Global), complete global trade liberalization including Mozambique (FL), and lastly, the Doha scenario (Doha). . These scenarios are described in detail earlier in this book. Due to its status as a Least Developed Country (LDC), Mozambique does not have to reduce its tariffs under the Doha scenario.

Results are presented in Tables 8, 9, and 10. Focusing first on the macroeconomic results in Table 8, one notes that unilateral trade liberalization generates a substantial real exchange rate depreciation. With tariffs removed, imports become more attractively priced and import volumes increase. In order to obtain the foreign currency to purchase these additional imports, exports must increase more than proportionately due to the large initial trade deficit. As mentioned above, in order to remain consistent with GTAP, export demand functions are specified as downward sloping. Therefore, the growth in export volume results in somewhat lower prices for export commodities leading to a deterioration in the terms of trade. Devaluation helps to attenuate the import surge and provides additional incentives to exporting sectors. Global trade liberalization with Mozambique not participating operates through shifts in world demand curves for Mozambican export commodities as described above. It turns out that global trade liberalization tends to improve the terms of trade for Mozambique permitting increased imports even though exports remain flat. The results for the third scenario, FL, are essentially an additive combination of the first two simulations.

Turning to the Doha scenario, the terms of trade effect is negative for Mozambique - as a consequence of the elimination of export subsidies and the erosion of Mozambican tariff preferences in industrial countries. The negative terms of trade shock is accommodated primarily through compression of imports (recall that initial import 
values are much larger than export values). A relatively large decline in the export price for the Fisheries sector, an important exporter, helps to explain both the direction of the terms of trade shock and the compression of import values.

Overall household welfare as calculated from the CGE model (Table 9) is driven largely by the terms of trade. The presence of downward sloping export demand functions are a particularly important element in the terms of trade changes when domestic trade liberalization is considered. By contrast, with the small country assumption (constant world prices) and operatively small export transformation elasticities, unilateral trade liberalization tends to improve household welfare (scenario not shown). In all scenarios, the impacts on welfare are not particularly large.

Microsimulation analysis generally points to similarly small results. Table 10 summarizes the implications of trade liberalization on household welfare for the lower four income quintiles. It shows the mean, minimum, and maximum household level welfare impact (in percentage change from the base) for each simulation. The mean effect in the microsimulation model tends to be closer to zero than the equivalent welfare calculation provided in Table 9. This is due primarily to the insulating effects of the high value of home consumption in the lower $80 \%$ of the consumption distribution (see Table 4). Nevertheless, concentration of earnings sources in certain factors and consumption on certain commodities exposes some households to stronger than average effects of trade liberalization. The range of the distribution is captured by the maximum and minimum values. The worst affected household would be one specialized in the factor with least favorable change in factor prices and specialized in consumption of commodities whose prices have tended to rise. 
The range of outcomes for the Doha scenario is presented in Figure 1. Outcomes for both urban and rural households tend to concentrate near the mean. Nevertheless, impacts tend to be much more heterogeneous in urban than in rural areas. This result also holds in all of the other scenarios (histograms not shown). This occurs due to more heterogeneous factor endowments across households in urban areas (rural households tend to depend very heavily on unskilled labor) as well as substantially greater reliance on the market for the purchase of commodities (i.e. less own-consumption). For rural households, homogeneity in income sources tends to concentrate welfare outcomes near the mean, and the prevalence of home consumption implies that this mean effect is typically quite small.

Since nearly three out of four poor Mozambicans live in rural areas, the overall implications for poverty rates in all of the scenarios tend to be small. In the scenario with the largest effect, unilateral trade liberalization (Unilib), the poverty rate edges up from 54.1 percent nationwide to 54.4 percent. Impacts in the remaining scenarios are much smaller.

\section{Limitations of the Analysis}

\subsection{Price transmission}

As reviewed in Winters, McCulloch, and McKay (2004), Marketing costs between the frontier of a country (the port for example) and the point of production cause the price of an export good at the point of production to be considerably more variable in proportional terms than the FOB price. For example, consider a good with an export price at the border of 100 and a marketing wedge between the border and the farm/factory gate 
of 50. If the FOB price increases by 10 percent to 110 and the marketing wedge remains constant, then the farm/factory gate price also increases by 10 from 50 to 60 for a proportionately double price increment of 20 percent.

The inverse happens with respect to importation. Consider an imported good that is available at the border for a price of 50 . Marketing costs of 50 are incurred to get the product to the point of final consumption. If the border price increases by 10 percent and marketing costs remain constant, then the price of the imported good at the point of consumption increases by only five percent. Therefore, in terms of proportional price changes, marketing wedges tend to expand the impact of changes in export prices (FOB minus export taxes) and dampen the impact of changes in import prices (CIF plus import tariffs). If border price changes are transmitted in the manner above, it seems likely that past assessments of the implications of past global trade negotiation rounds may have given undue weight to the implications of import price changes and insufficient weight to the implications of export price changes when considering the implications of trade agreements for poverty and well being for many parts of Africa.

The current model, with its explicit addition of margins for exports, imports, and domestics, partially captures these effects. This represents an important step forward; however, there remains much to do. The impact of trade liberalization on poverty depends crucially upon where the poor are living and the strength of the ensuing links to regional, national, and global markets. Distance and poor transport infrastructure alone may sever links to both import and export markets. Imperfect competition within the marketing system may also sever market linkages (Moser and Minten 2004). Thus, particularly in large countries such as Mozambique, the analysis of trade and poverty 
forces one to consider building models with finer levels of spatial detail. This is true for both commodity and factor markets.

Unfortunately, attaining enhanced spatial detail is easier said than done. Attempts have been made (Ferreira-Filho and Horridge, 2005) in this volume; however, these attempts tend to be partial and tend not to generate a spatial price map that reflects the appropriate distribution of prices over space. ${ }^{8}$ This is crucial as more distant regions often exhibit higher rates of poverty and very high marketing wedges. While a partial approach to regionalization (for example, regional detail in the production of some agricultural commodities for example) within an AGE model seems attractive initially, the incompleteness might actually hamper the goal of more faithfully modeling the role of geography in shaping the impact of policy change. Therefore, despite formidable information lacunae on the spatial distribution of economic activity and the complete absence of information on inter-regional trade, it may be better to develop regional social accounting matrices that account for what is known about the regional distribution of economic activity, estimating the remainder under plausible assumptions. ${ }^{9}$

\subsection{Revenue replacement}

In the case of Mozambique, the GTAP model employs average tariffs obtained by multiplying applied tariff rates by import weights. To remain consistent, the country CGE model also employs these average tariff values. However, as discussed in Arndt and Tarp (2004), published tariff rates are generally larger than the tariff rate implied by the average tariff rate due to official exemptions and/or smuggling. If the marginal import

\footnotetext{
${ }^{8}$ The distribution of prices over time is another important element.

${ }^{9}$ Another option is to link the results of a CGE model to a partial equilibrium model(s) in order to flesh out in more detail implications for important sectors.
} 
pays published tariff rates, then the published tariff rate and not the average rate is the operative one for trade policy analysis. In addition, the rents associated with smuggling and official tariff exemptions may be large. Elimination or reduction of these rents through trade liberalization can have substantial distribution effects often with positive welfare implications for the poor (as the poor typically do not profit from these rents in the initial situation).

Gaps between average and published tariff rates also have implications for revenue. Pritchett and Sethi (1994) find that the gap between these rates tends to fall as published tariff rates decline. Hence, higher collection ratios may substantially attenuate declines in revenues due to lower tariff rates. The heavy dependence of Mozambique and many other African countries on value added taxes (VAT) applied at the border implies that even complete trade liberalization (tariff rates zero) may have offsetting revenue implications if a higher share of import volumes pass through official channels and hence pay VAT.

Examination of these revenue issues in the Mozambican context goes beyond the scope of the current paper (though it is an important topic for future research). The use of a neutral income tax for revenue replacement is a poor substitute for realistic modeling of revenue replacement options; however, the complexities of the revenue replacement issue (see Arndt and Tarp 2004) precluded modeling of options that are effectively more realistic within the time frame available for this analysis.

\subsection{Downward sloping export demand functions}

In the analysis undertaken in this paper, trade liberalization by Mozambique results in increased export volumes. Since the country is presumed to face downward 
sloping export demand functions, increases in exports results in lower prices and a deterioration in the nation's terms of trade. This formulation permits consistency with the GTAP model. Unfortunately, the formulation is the major driver of welfare results in the scenarios where Mozambique undertakes own liberalization. While perhaps a reasonable specification for some sectors, exports from many sectors are likely constrained by supply factors. In this view, more could be exported at a constant price if more could be produced. In fact, for many sectors, low export volumes are often pointed to as a cause of low prices, particularly at the farm or factory gate. Low volumes are viewed as a cause of high marketing costs and diminished confidence of potential importers in the quality and reliability of supply of Mozambican products. As indicated earlier, the changing the modeling assumption to that of supply-constrained exports and constant world prices switches the sign on the welfare result for unilateral trade liberalization, although the implications remain relatively small for the same reasons discussed above.

Despite these limitations of the analytical framework employed in this paper, a few robust conclusions may effectively be drawn. These are discussed in the final section.

\section{Conclusions}

In order to rise out of poverty, Mozambique must achieve rapid growth over a long period of time. Even with rapid growth, it will take some time, perhaps decades, to lift the large bulk of the Mozambican population out of poverty. Seen from this perspective, the static results presented above are disappointing as they do not contribute to the growth required for such sustained poverty reduction. Nevertheless, as pointed out 
by Winters, McCulloch, and McKay (2004), most economists believe that more liberal trading regimes tend to be associated with higher rates of economic growth. Difficulties, in their view, come about in making the transition from more restrictive to more open trade regimes. In this respect, the results of this paper may be viewed in a more positive light. For Mozambique, the short-term poverty impacts of moving to a liberal trade regime appear to be relatively small. Hence, Mozambique has the opportunity to set in place the liberal trade element of a growth strategy at relatively low short-term adjustment cost.

It is well recognized that, especially in the Mozambican context, low or zero barriers to imports are not a sufficient condition for ensuring poverty reducing economic growth. A key element to sustaining growth over the coming decades very likely involves substantially expanding the volume of exports in sectors where volumes are currently very small, or breaking into new export markets entirely. A liberal import regime helps set the stage for export expansion; however, such expansion will not occur without appropriate complementary policies aimed at improving price transmission to rural areas, as well as facilitating producer supply response. Only after such reforms will the vast majority of poor in Mozambique be able to take advantage of the improved world market opportunities that are expected to follow from global trade reforms. 


\section{References}

Arndt, C., H.T. Jensen, S. Robinson, and F. Tarp 2000. "Agricultural Technology and Marketing Margins in Mozambique”, Journal of Development Studies, vol. 37 (1) pp. 121-137.

Arndt, C., and H.T. Jensen, F. 2000 "Stabilization and Structural Adjustment in Mozambique.” Journal of International Development 12: 299-323.

Arndt, C. and F. Tarp 2004. "Trade Policy Reform and the Missing Revenue: An Application to Mozambique.” Mimeo.

Chen, S. and M. Ravallion 2004. "Welfare Impacts of China's Accession to the World Trade Organization.” World Bank Economic Review 18(1): 29-57.

Ferreira-Filho, J.B.S. and M. Horridge 2005. "The Doha Round, Poverty and Regional Inequality in Brazil." Poverty and the WTO: Impacts of the Doha Development Agenda. Thomas W. Hertel and L. Alan Winters (eds.), New York: Palgrave Macmillan, 2005.

Hertel, T., D. Hummels, M. Ivanic, and R. Keeney 2004. "How Confident Can We Be in CGE-Based Assessments of Free Trade Agreements?” Global Trade Analysis Project Technical Paper 26, www.gtap.org.

Horridge, M. 2004. "Shocking a single country CGE model with export prices/quantities from GTAP.” Centre of Policy Studies, Monash University. Mimeo.

INE (Instituto Nacional de Estatística) 2004. Inquérito Nacional aos Agregados Familiares Sobre Orçamento Familiar 2002/3 (National Household Budget Survey) Maputo, www.ine.gov.mz.

James, R.C., C. Arndt, and K.R. Simler 2005. "Has economic growth in Mozambique been pro-poor?" National Directorate of Planning and Budget, Ministry of Planning and Finance, Mozambique.

Löfgren, H., R.L. Harris, S. and Robinson 2001. "A Standard Computable General Equilibrium (CGE) Model in GAMS.” Trade and Macroeconomics Discussion Paper no. 75, International Food Policy Research Institute, Washington, DC, USA.

Maximiano, N. 2005. “A Dinamica dos Determinantes de Pobreza.” (The Dynamics of Poverty Determinants). National Directorate of Planning and Budget, Ministry of Planning and Finance, Mozambique.

Moser, C. and B. Minten 2004. "Missed opportunities and missing markets: Spatiotemporal arbitrage of rice in Madagascar." Paper presented at TIPS/DPRU Forum 2004: African Development and Poverty Reduction: The Macro-Micro Linkage. 
MPF/IFPRI/PU (Mozambique Ministry of Planning and Finance/ International Food Policy Research Institute/Purdue University). 2004. Poverty and well-being in Mozambique: The Second National Assessment (2002-2003). National Directorate of Planning and Budget, Ministry of Planning and Finance, Mozambique.

Pritchett, L. and G. Sethi 1994. "Tariff Rates, Tariff Revenue, and Tariff Reform: Some New Facts.” World Bank Economic Review 8(1): 1-16.

Tarp, F., Arndt, C., Jensen, H. T., Robinson, S., and Heltberg, R. 2002. Facing the Development Challenge in Mozambique: An Economy-wide Perspective. IFPRI Research Report No. 126, Washington, D.C.

Uganda 2003. Uganda National Household Survey 2002/2003. Uganda Bureau of Statistics.

Winters, L.A., N. McCulloch, and A. McKay 2004. "Trade Liberalization and Poverty: The Evidence So Far.” Journal of Economic Literature 42: 72-115. 
Figure 1: Histogram of welfare outcomes for the Doha scenario

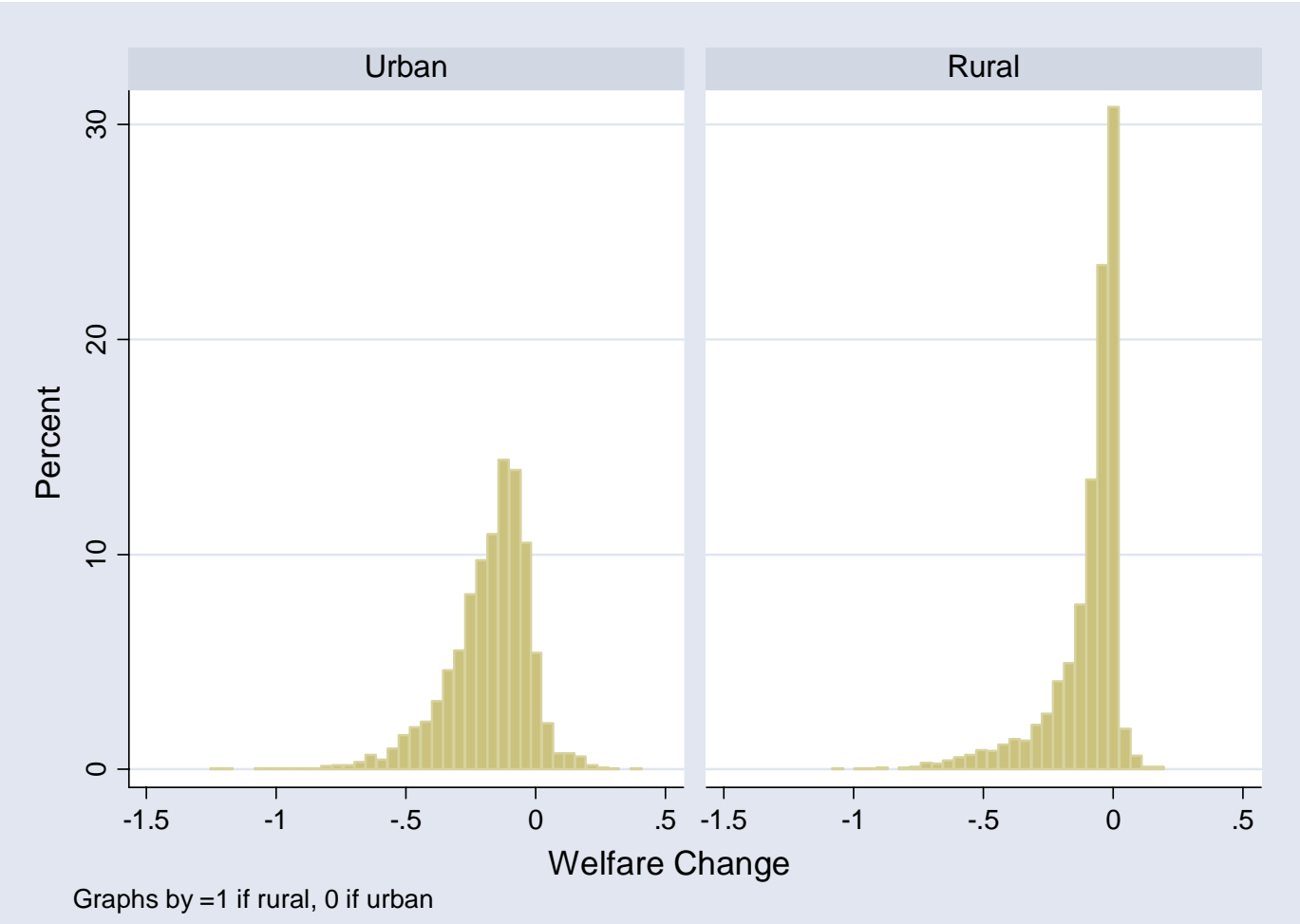


Table 1 Components of GDP

\begin{tabular}{lr}
\hline & \multicolumn{1}{c}{ Share (\%) } \\
\hline Private Consumption & 72.4 \\
Private Investment & 11.2 \\
Government & 28.9 \\
Exports & 20.6 \\
Imports & -33.0 \\
Total & 100.0 \\
\hline
\end{tabular}

Table 2a Sectoral shares in value added, exports and imports

\begin{tabular}{lcccrr}
\hline Sector & $\begin{array}{c}\text { Value } \\
\text { Added } \\
\text { Share }(\%)\end{array}$ & $\begin{array}{c}\text { Export } \\
\text { Share } \\
(\%)\end{array}$ & $\begin{array}{c}\text { Import } \\
\text { Share } \\
(\%)\end{array}$ & $\begin{array}{r}\text { Avg. } \\
\text { Tariff } \\
\text { Rate }\end{array}$ & $\begin{array}{c}\text { GTAP } \\
\text { Tariff } \\
\text { Rate }\end{array}$ \\
\hline Paddy rice & 1.0 & 0.0 & 0.0 & 0.0 & 2.3 \\
Wheat & 0.0 & 0.0 & 1.9 & 2.4 & 2.1 \\
Cereal grains nec & 2.1 & 0.2 & 0.3 & 2.0 & 2.3 \\
Vegetables, fruit, nuts & 3.8 & 1.9 & 0.1 & 23.0 & 23.0 \\
Oil seeds & 0.8 & 0.0 & 0.1 & 7.8 & 9.9 \\
Sugar cane, sugar beet & 0.2 & 0.0 & 0.0 & 0.0 & 0.0 \\
Plant-based fibers & 1.1 & 0.1 & 0.0 & 23.2 & 0.0 \\
Crops nec & 9.7 & 2.6 & 0.4 & 3.2 & 5.2 \\
Bovine cattle, sheep, goats, horses & 0.6 & 0.0 & 0.1 & 1.9 & 6.1 \\
Animal products nec & 1.1 & 0.0 & 0.5 & 10.4 & 4.7 \\
Forestry & 2.7 & 1.5 & 0.0 & 2.5 & 2.7 \\
Fishing & 2.5 & 12.6 & 0.0 & 22.4 & 6.8 \\
Minerals nec & 0.3 & 0.3 & 0.2 & 5.3 & 7.1 \\
Bovine meat products & 0.4 & 0.0 & 0.0 & 23.2 & 15.7 \\
Meat products nec & 1.2 & 0.2 & 1.0 & 8.9 & 19.4 \\
Vegetable oils and fats & 0.3 & 1.1 & 1.1 & 16.0 & 13.6 \\
Processed rice & 0.1 & 0.0 & 4.5 & 5.8 & 7.1 \\
Sugar & 0.1 & 0.5 & 0.6 & 5.3 & 7.5 \\
Food products nec & 2.5 & 0.6 & 3.4 & 9.2 & 18.3 \\
Beverages and tobacco products & 0.8 & 0.1 & 1.6 & 9.4 & 24.2 \\
Textiles & 0.4 & 2.6 & 3.8 & 11.5 & 20.7 \\
Wearing apparel & 0.6 & 0.6 & 0.5 & 21.7 & 24.0 \\
Leather products & 0.1 & 0.1 & 0.3 & 29.9 & 22.6 \\
Wood products & 0.7 & 0.4 & 1.1 & 14.6 & 18.0 \\
\hline
\end{tabular}


Table $2 b$ Sectoral shares in value added, exports and imports

\begin{tabular}{|c|c|c|c|c|c|}
\hline Sector & $\begin{array}{c}\text { Value } \\
\text { Added } \\
\text { Share (\%) }\end{array}$ & $\begin{array}{c}\text { Export } \\
\text { Share } \\
(\%)\end{array}$ & $\begin{array}{c}\text { Import } \\
\text { Share } \\
(\%)\end{array}$ & $\begin{array}{c}\text { Avg. } \\
\text { Tariff } \\
\text { Rate }\end{array}$ & $\begin{array}{c}\text { GTAP } \\
\text { Tariff } \\
\text { Rate }\end{array}$ \\
\hline Paper products, publishing & 0.0 & 0.0 & 0.8 & 9.5 & 6.5 \\
\hline Petroleum, coal products & 0.2 & 2.5 & 4.4 & 12.0 & 4.8 \\
\hline Chemical, rubber, plastic products & 0.4 & 0.3 & 19.0 & 6.7 & 9.4 \\
\hline Mineral products nec & 0.5 & 0.1 & 2.4 & 6.4 & 8.8 \\
\hline Ferrous metals & 4.5 & 49.0 & 0.2 & 9.6 & 6.3 \\
\hline Metal products & 0.2 & 0.4 & 6.3 & 5.1 & 9.9 \\
\hline Motor vehicles and parts & 0.0 & 0.0 & 6.1 & 7.9 & 8.6 \\
\hline Transport equipment nec & 0.0 & 0.2 & 9.5 & 7.8 & 11.5 \\
\hline Electronic equipment & 0.0 & 0.0 & 6.0 & 2.4 & 6.9 \\
\hline Manufactures nec & 0.0 & 0.2 & 1.6 & 21.6 & 21.9 \\
\hline Electricity & 1.9 & 7.8 & 4.2 & 0.0 & 0.0 \\
\hline Water & 0.3 & 0.0 & 0.0 & 0.0 & 0.0 \\
\hline Construction & 9.4 & 0.0 & 0.0 & 0.0 & 0.0 \\
\hline Trade & 17.3 & 0.0 & 0.0 & 0.0 & 0.0 \\
\hline Transport nec & 7.2 & 6.5 & 0.0 & 0.0 & 0.0 \\
\hline Water transport & 0.2 & 0.0 & 0.0 & 0.0 & 0.0 \\
\hline Air transport & 0.4 & 0.0 & 0.0 & 0.0 & 0.0 \\
\hline Communication & 1.8 & 0.0 & 0.0 & 0.0 & 0.0 \\
\hline Financial services nec & 2.0 & 0.5 & 0.2 & 0.0 & 0.0 \\
\hline Insurance & 0.1 & 0.0 & 0.3 & 0.0 & 0.0 \\
\hline Business services nec & 3.7 & 4.7 & 16.3 & 0.3 & 0.0 \\
\hline Public Admin., Def., Educ., Health & 16.3 & 2.5 & 1.1 & 0.0 & 0.0 \\
\hline Dwellings & 0.4 & 0.0 & 0.0 & 0.0 & 0.0 \\
\hline Total & 100.0 & 100.0 & 100.0 & & \\
\hline
\end{tabular}


Table 3 Indications of import competition

\begin{tabular}{l|c|cc}
\hline & Overall & \multicolumn{2}{|c}{ Specialized $^{1}$} \\
\cline { 3 - 4 } & $\begin{array}{c}\text { Production } \\
\text { Value } \\
\text { Share }\end{array}$ & $\begin{array}{c}\text { Share of } \\
\text { Total } \\
\text { Supply }\end{array}$ & $\begin{array}{c}\text { Share of } \\
\text { Production }\end{array}$ \\
\hline Total Economy & $100.0 \%$ & $82.1 \%$ & $88.8 \%$ \\
Agriculture, Forestry and Fisheries & $15.1 \%$ & $98.2 \%$ & $98.5 \%$ \\
Primary Product Processing & $12.9 \%$ & $46.1 \%$ & $53.4 \%$ \\
Other goods & $8.1 \%$ & $74.6 \%$ & $74.5 \%$ \\
Services & $63.9 \%$ & $89.1 \%$ & $95.5 \%$ \\
\hline
\end{tabular}

${ }^{1}$ The figures in the above Table are drawn from production and import information for 144 sectors representing all commodities. The intent is to discover which productive sectors compete intensively with imports and which are specialized meaning that either commodity supply comes $90 \%$ from domestic production or $90 \%$ from imports.

Table 4 Share of value of home consumption in total consumption

\begin{tabular}{l|rrr}
\hline & Urban & Rural & Total \\
\hline Macroeconomic Share & 7.8 & 35.7 & 22.0 \\
Population Weight Share & 15.7 & 58.2 & 44.6 \\
Poor Pop. Weight Share & 19.5 & 59.2 & 47.1 \\
\hline
\end{tabular}

Table 5: Consumption by quintiles.

\begin{tabular}{c|c|c}
\hline $\begin{array}{c}\text { Population } \\
\text { Quintile }\end{array}$ & $\begin{array}{c}\text { Real Consumption } \\
\text { Index }\end{array}$ & $\begin{array}{c}\text { As ratio of highest } \\
\text { quintile’s consumption }\end{array}$ \\
\hline $0-20 \%$ & 0.39 & 7.97 \\
$21-40 \%$ & 0.66 & 4.63 \\
$41-60 \%$ & 0.94 & 3.29 \\
$61-80 \%$ & 1.32 & 2.34 \\
$81-100 \%$ & 3.08 & 1.00 \\
Mean & 1.28 & 2.41 \\
\hline
\end{tabular}


Table 6a: Export and import price changes and tariff cuts for simulations

\begin{tabular}{|c|c|c|c|c|c|c|}
\hline & \multicolumn{3}{|c|}{ Global Liberalization } & \multicolumn{3}{|c|}{ Doha } \\
\hline & $\begin{array}{c}\text { Export } \\
\text { Prices }\end{array}$ & $\begin{array}{c}\text { Import } \\
\text { Prices }\end{array}$ & $\begin{array}{l}\text { Export } \\
\text { Quant. }\end{array}$ & $\begin{array}{c}\text { Export } \\
\text { Prices }\end{array}$ & $\begin{array}{r}\text { Import } \\
\text { Prices }\end{array}$ & $\begin{array}{l}\text { Export } \\
\text { Quant. }\end{array}$ \\
\hline Paddy rice & NA & 12.8 & NA & NA & 2.9 & NA \\
\hline Wheat & NA & 6.7 & NA & NA & 1.5 & NA \\
\hline Cereal grains nec & 1.6 & 3.4 & -5.2 & 0.0 & 1.6 & 1.8 \\
\hline Vegetables, fruit, nuts & 1.4 & 2.7 & 14.6 & 0.0 & 0.9 & -4.3 \\
\hline Oil seeds & 3.3 & 6.4 & 56.5 & 0.7 & 2.2 & 11.7 \\
\hline Sugar cane, sugar beet & NA & NA & NA & NA & NA & NA \\
\hline Plant-based fibers & 3.5 & 1.1 & 26.9 & 1.0 & 1.2 & 9.0 \\
\hline Crops nec & 2.0 & 0.7 & 20.9 & 0.0 & 0.7 & -2.4 \\
\hline Bovine cattle, sheep, goats, horses & NA & 3.3 & NA & NA & 1.7 & NA \\
\hline Animal products nec & 1.6 & 2.1 & -6.3 & 0.1 & 1.2 & -1.7 \\
\hline Forestry & -0.9 & -0.2 & 3.0 & -0.3 & 0.1 & 1.8 \\
\hline Fishing & -2.4 & 0.4 & 9.5 & -0.7 & 0.4 & 0.5 \\
\hline Minerals nec & -0.8 & 1.1 & 2.2 & 0.0 & 1.7 & 0.7 \\
\hline Bovine meat products & NA & 3.4 & NA & NA & 2.0 & NA \\
\hline Meat products nec & 1.2 & 1.4 & -37.7 & 0.1 & 1.0 & -12.6 \\
\hline Vegetable oils and fats & 0.5 & 2.6 & -16.2 & 0.2 & 1.2 & 4.0 \\
\hline Processed rice & 2.2 & 5.6 & -6.8 & 0.2 & 3.0 & -2.1 \\
\hline Sugar & 0.0 & 1.3 & 54.9 & 0.0 & 1.3 & 17.0 \\
\hline Food products nec & 0.1 & -0.1 & -16.1 & -0.1 & 0.6 & -4.4 \\
\hline Beverages and tobacco products & -0.7 & -0.7 & -6.5 & -0.1 & 0.2 & -2.1 \\
\hline Textiles & -0.1 & -1.3 & -2.4 & 0.1 & 0.7 & -3.8 \\
\hline Wearing apparel & -1.0 & -2.0 & 22.7 & -0.2 & -0.4 & 1.7 \\
\hline Leather products & -0.8 & -0.9 & -8.6 & 0.0 & 0.2 & -8.8 \\
\hline Wood products & -1.0 & -1.1 & -5.3 & -0.2 & -0.2 & -1.1 \\
\hline
\end{tabular}

Note: NA applies to commodities where import or export volumes are zero. 
Table 6b: Export and Import Price Changes and Tariff Cuts (continued)

\begin{tabular}{|c|c|c|c|c|c|c|}
\hline & \multicolumn{3}{|c|}{ Global Liberalization } & \multicolumn{3}{|c|}{ Doha } \\
\hline & $\begin{array}{c}\text { Export } \\
\text { Prices }\end{array}$ & $\begin{array}{r}\text { Import } \\
\text { Prices }\end{array}$ & $\begin{array}{l}\text { Export } \\
\text { Quant. }\end{array}$ & $\begin{array}{c}\text { Export } \\
\text { Prices }\end{array}$ & $\begin{array}{c}\text { Import } \\
\text { Prices }\end{array}$ & $\begin{array}{l}\text { Export } \\
\text { Quant. }\end{array}$ \\
\hline Paper products, publishing & -0.4 & 1.6 & 25.2 & 0.4 & 2.5 & -3.9 \\
\hline Petroleum, coal products & -1.0 & -0.8 & 16.0 & -0.3 & 0.0 & 1.7 \\
\hline Chemical, rubber, plastic products & -1.0 & -0.4 & 112.5 & -0.2 & 0.8 & 39.9 \\
\hline Mineral products nec & -0.8 & 2.8 & -8.3 & 0.0 & 3.5 & -2.9 \\
\hline Ferrous metals & -1.0 & -0.7 & -7.6 & -0.2 & 0.0 & -0.8 \\
\hline Metal products & -0.9 & -1.0 & -21.9 & 0.0 & -0.1 & -3.6 \\
\hline Motor vehicles and parts & NA & -2.9 & NA & NA & -0.4 & NA \\
\hline Transport equipment nec & -1.0 & -0.9 & -1.0 & -0.1 & -0.1 & -0.1 \\
\hline Electronic equipment & NA & -1.0 & NA & NA & -0.1 & NA \\
\hline Manufactures nec & -1.0 & -1.1 & 1.5 & -0.1 & -0.1 & -0.3 \\
\hline Electricity & -0.9 & -1.0 & 2.1 & -0.1 & -0.1 & 1.6 \\
\hline Water & NA & NA & NA & NA & NA & NA \\
\hline Construction & NA & NA & NA & NA & NA & NA \\
\hline Trade & NA & NA & NA & NA & NA & NA \\
\hline Transport nec & -1.0 & NA & 1.3 & -0.2 & NA & 0.4 \\
\hline Water transport & NA & NA & NA & NA & NA & NA \\
\hline Air transport & NA & NA & NA & NA & NA & NA \\
\hline Communication & NA & NA & NA & NA & NA & NA \\
\hline Financial services nec & -1.2 & -0.7 & 2.4 & -0.3 & -0.1 & 1.0 \\
\hline Insurance & NA & -0.8 & NA & NA & -0.2 & NA \\
\hline Business services nec & -1.0 & -0.7 & 1.2 & -0.2 & -0.1 & 0.2 \\
\hline Public Admin., Def., Educ., Health & -0.8 & -0.8 & 0.2 & -0.2 & -0.1 & 0.4 \\
\hline Dwellings & NA & NA & NA & NA & NA & NA \\
\hline
\end{tabular}

Note: NA applies to commodities where import or export volumes are zero. 
Table 7: Simulations

\begin{tabular}{ll}
\hline Simulation & Description \\
\hline UniLib & Unilateral complete trade liberalization by Mozambique uniquely. \\
Global & Complete global trade liberalization excluding Mozambique. \\
FL & Complete global trade liberalization including Mozambique. \\
Doha & Doha \\
\hline
\end{tabular}

Table 8: Macroeconomic indicators

\begin{tabular}{lrrrr}
\hline & UniLib & Global & \multicolumn{1}{c}{ FL } & \multicolumn{1}{c}{ Doha } \\
\hline Total Absorption & -0.7 & 0.6 & 0.0 & -0.2 \\
Real Exports & 4.4 & 0.0 & 4.4 & 0.2 \\
Real Imports & 0.5 & 1.9 & 2.4 & -0.4 \\
Real Exchange Rate & 4.3 & -3.4 & 0.8 & 0.4 \\
Terms of Trade & -1.4 & 0.8 & -0.6 & -0.7 \\
\hline
\end{tabular}

Table 9: Equivalent variation for households (percentage change, relative to base)

\begin{tabular}{lrrrrr}
\hline & Base & UniLib & Global & \multicolumn{1}{c}{ FL } & \multicolumn{1}{c}{ Doha } \\
\hline Urban & 2538.74 & -0.552 & 0.489 & -0.088 & -0.219 \\
Rural & 2631.26 & -0.75 & 0.527 & -0.192 & -0.173 \\
Total & 5170 & -0.653 & 0.508 & -0.141 & -0.195 \\
\hline
\end{tabular}


Table 10: Microsimulation percentage changes in welfare by quintile

\begin{tabular}{|c|c|c|c|c|c|}
\hline \multicolumn{6}{|c|}{ RURAL } \\
\hline Quintile & Statistic & UniLib & Global & FL & Doha \\
\hline $0-20 \%$ & mean & -0.65 & 0.14 & -0.49 & -0.10 \\
\hline $21-40 \%$ & mean & -0.62 & 0.11 & -0.48 & -0.09 \\
\hline $41-60 \%$ & mean & -0.55 & 0.14 & -0.38 & -0.09 \\
\hline $61-80 \%$ & mean & -0.43 & 0.15 & -0.24 & -0.09 \\
\hline $0-20 \%$ & $\max$ & 1.99 & 2.16 & 2.64 & 0.17 \\
\hline $21-40 \%$ & $\max$ & 2.61 & 2.56 & 3.29 & 0.14 \\
\hline $41-60 \%$ & $\max$ & 1.71 & 2.05 & 2.87 & 0.17 \\
\hline $61-80 \%$ & $\max$ & 3.19 & 1.31 & 4.21 & 0.16 \\
\hline $0-20 \%$ & $\min$ & -1.37 & -0.69 & -1.70 & -1.06 \\
\hline $21-40 \%$ & $\min$ & -1.90 & -0.66 & -1.89 & -0.96 \\
\hline $41-60 \%$ & $\min$ & -1.43 & -0.85 & -2.16 & -0.90 \\
\hline $61-80 \%$ & $\min$ & -1.72 & -0.90 & -2.62 & -0.93 \\
\hline \multicolumn{6}{|c|}{ URBAN } \\
\hline Quintile & Statistic & UniLib & Global & $\mathrm{FL}$ & Doha \\
\hline $0-20 \%$ & mean & -0.29 & 0.08 & -0.23 & -0.18 \\
\hline $21-40 \%$ & mean & -0.27 & 0.13 & -0.16 & -0.19 \\
\hline $41-60 \%$ & mean & -0.10 & 0.17 & 0.05 & -0.18 \\
\hline $61-80 \%$ & mean & -0.02 & 0.31 & 0.27 & -0.20 \\
\hline $0-20 \%$ & $\max$ & 2.39 & 1.53 & 3.38 & 0.25 \\
\hline $21-40 \%$ & $\max$ & 3.05 & 1.65 & 4.02 & 0.29 \\
\hline $41-60 \%$ & $\max$ & 2.61 & 2.27 & 3.17 & 0.37 \\
\hline $61-80 \%$ & $\max$ & 2.64 & 2.15 & 3.48 & 0.20 \\
\hline $0-20 \%$ & $\min$ & -1.78 & -0.89 & -1.95 & -0.96 \\
\hline $21-40 \%$ & $\min$ & -2.21 & -1.09 & -2.36 & -1.25 \\
\hline $41-60 \%$ & $\min$ & -2.03 & -0.99 & -2.47 & -1.17 \\
\hline $61-80 \%$ & $\min$ & -1.91 & -0.91 & -1.89 & -1.07 \\
\hline
\end{tabular}

Note: The top earning quintile is not presented due to difficulties in separating labor and capital income for this group of households. 